PERM JOURNAL OF PETROLEUM AND MINING ENGINEERING

ВЕСТНИК ПНИПУ. ГЕОЛОГИЯ. НЕФТЕГАЗОВОЕ И ГОРНОЕ ДЕЛО

ISSN 2224-9923

Volume/ Toм 16 №3 2017

http://vestnik.pstu.ru/geo

УДК 553.981/.983

Article / Статья

(C) PNRPU / ПНИПУ, 2017

\title{
PHYSICAL AND RESERVOIR PROPERTIES OF POTENTIAL OIL AND GAS BEARING INTERVALS AT THE BOTTOM OF PRODUCTIVE THICKNESS ONSHORE IN AZERBAIJAN (AT THE EXAMPLE OF KALAMADDIN FIELD)
}

\author{
Vagif Sh. Gurbanov, Adalat B. Gasanov, Nariman R. Narimanov, Latif A. Sultanov, Shura A. Ganbarova \\ Azerbaijan State Oil and Industrial University (20 Azadlyg av., Baku, AZ1010, Republic of Azerbaijan)

\section{ФИЗИЧЕСКИЕ ХАРАКТЕРИСТИКИ И ФИЛЬТРАЦИОННО-ЕМКОСТНЫЕ СВОЙСТВА ПЕРСПЕКТИВНЫХ НЕФТЕГАЗОНОСНЫХ ГОРИЗОНТОВ В НИЗАХ ПРОДУКТИВНОЙ ТОЛЩИ НА СУХОПУТНЫХ ПЛОЩАДЯХ АЗЕРБАЙДЖАНА (НА ПРИМЕРЕ МЕСТОРОЖДЕНИЯ КАЛАМАДДИН)}

\section{В.Ш. Гурбанов, А.Б. Гасанов, Н.Р. Нариманов, Л.А. Султанов, Ш.А. Ганбарова}

Азербайджанский государственный университет нефти и промышленности (1010, Республика Азербайджан, г. Баку, пр. Азадлыг, 20) Received / Получена: 26.04.2017. Accepted / Принята: 12.07.2017. Published / Опубликована: 15.09.2017

Key words:

rocks, set, porosity, depth, well, density, petrophysics, interval, drilling, geophysics, oil and gas deposition.

\begin{abstract}
During the last years drilling exploration works in the Republic of Azerbaijan have been moved from east regions to less studied central and west regions. Besides, generalization of available geological and geophysical data, evaluation of potential of certain lithologic and stratigraphic complexes and forecast of deep oil and gas reservoirs are of particular importance. The paper shows an analysis of complex petrophysical data. An analysis considers interpretation of reservoir and petrophysical properties of rocks of Mesozoic and Cenozoic deposits taken from drilled wildcat and appraisal wells and geological data of Kalamaddin oil and gas Mesozoic and Cenozoic deposits taken from drilled wildcat and appraisal wells and geological data
bearing region where sediments of productive thickness (PT) such as Lower Pliocene are widely spread. bearing region where sediments of productive thickness (PT) such as Lower Pliocene are widely spread. bearing reservoirs are represented mostly by naturally fractured igneous-sedimentary and carbonate rocks. Petrophysical properties of rocks of a section of the earth's crust of Kalamaddin oil and gas bearing region are given in short. Based on the generalized data a schematic graph that reflects change in rock porosity along a section is built. According to a graph the deeper is the formation the lower rock porosity and the higher the density and propagation velocity of ultrasonic waves are. Obtained generalizations allow to conclude that change in reservoir properties in a wide range on the territory of Kalamaddin is connected to lithological heterogeneity conclude that change in reserve he heterogeneity of rock complexes, diversity of their burial depths and as a result with diversity of pressure and temperature conditions and complexity of tectonic conditions. Results of different petrophysical study methods show that reservoir properties of rocks become
worse if depth is increased. Nevertheless, in certain cases reservoir properties of clay and carbonate rocks can be improved due to worse if depth is increased. Nevertheless, in certain cases reservoir properties
secondary porosity under relatively rough pressure and temperature conditions.

Besides, relations between physical parameters and matter composition for certain rock types are established. Studies were performed in atmosphere and thermodynamic conditions.
\end{abstract} В последние годы в Республике Азербайджан осуществляется передислокация буровых разведочных работ из восточных районов в менее изученные центральные и западные. При этом особую важность обретают обобщение имеющегося геологогеофизического материала, оценка перспективности отдельных литолого-стратиграфических комплексов и прогнозирование глубокозалегающих нефтегазовых резервуаров. В данной работе приведен анализ комплексных петрофизических данных. При этом интерпретировались коллекторские и петрофизические свойства пород мезокайнозойских отложений, взятьх из пробуренных поисково-разведочных скважин и геологического материала площадей Каламаддинского нефтегазоносного пробуренных поисково-разведочных скважин и геологического материала площадей

района, где широко распространены отложения продуктивной толщи - нижний плиоцен. к нефтегазоносным коллекторам относятся в основном трещиноватые вулканогенно-осадочные и карбонатные породы. Приведены краткие петрофизические характеристики пород разреза земной коры Каламаддинского нефтегазоносного района. На основании обобщенных данных был составлен схематический график, отражающий изменение пористости пород по разрезу. Согласно этому графику с глубиной пористость пород уменьшается, а плотность и скорость распространения ультразвуковых волн повышаются. Полученные обобщения позволяют прийт к выводу, что изменене коллекторских свойств пород в широком диапазоне по плочади Каламаддин в в и в язи с этим с различием термобарических и сложностью тектонических условий. Результаты разных петрофизических методов исследований показывают, что коллекторские свойства пород в целом ухудшаются с глубиной. Однако в отдельных случаях в глинистых и карбонатных породах коллекторские свойства могут улучшиться за счет появления вторичной пористости при относительно жестких термобарических условиях.

Кроме того, установлены зависимости между физическими параметрами и вещественным составом для отдельных разновидностей пород. Исследования проводились в атмосферных и термодинамических условиях.

Vagif Sh. Gurbanov (Author ID in Scopus: 26028826000) - Doctor of Geology and Mineralogy, Professor (mob. tel.: +994 502 140 969, e-mail: vagifqurbanov@mail.ru). Adalat B. Gasanov - Doctor of Physics and Mathematics, Head of the Laboratory of Physical Properties of Rocks of the Fields of Mineral Resources (mob. tel.: +994 502 231 255, e-mail: adalathasanov@yahoo.com).

Nariman R. Narimanov (Author ID in Scopus: 6506800118) - PhD in Geology and Mineralogy, Associate Professor at the Department of Oil and Gas Geology (mob. tel.: +994503 073 321, e-mail: n.narimanov@asoiu.edu.az).

Latif A. Sultanov - Research Fellow at the Laboratory of Physical Properties of Rocks of the Fields of Mineral Resources (mob. tel.: + 994503 279 701, e-mail: latif.sultan@mail.ru). The contact person. Shura A. Ganbarova - Research Fellow at the Laboratory of Physical Properties of Rocks of the Fields of Mineral Resources (mob. tel.: + 994 505 311 276, e-mail: qanbarova1964@mail.ru).

Гурбанов Вагиф Шыхы оглы - доктор геолого-минералогических наук, профессор (моб. тел.: +994 502 140 969, e-mail: vagifqurbanov@mail.ru).

Гасанов Адалат Бадал оглы - доктор физико-математических наук, заведующий лабораторией физических свойств горных пород месторождений полезных ископаемых (моб. тел.: +994 502231255 , e-mail: adalathasanov@yahoo.com).

Нариманов Нариман Рустам оглы - кандидат геолого-минералогических наук, доцент кафедры геологии нефти и газа (моб. тел.: +994 503 073 321, e-mail: n.narimanov@asoiu.edu.az). Султанов Латиф Ӓгамирза оглы - научный сотрудник лаборатории физических свойств горных пород месторождений полезных ископаемых (моб. тел.: +994503 279 701, e-mail: latif.sultan@mail.ru). Контактное лицо для переписки.

Ганбарова Шvра Али кызы - научный сотрудник лаборатории физических свойств горных пород месторождений полезных ископаемых (моб. тел.: +994 505 311276 , e-mail: qanbarova1964@mail.ru). 


\section{Introduction}

Thanks to the big amount of hydrocarbon reserves Azerbaijan is well known and has a special status over the entire Transcaucasia. At the same time, it is established that the total area of potential oil and gas bearing (OGBA) onshore part of Azerbaijan is $54 \%$ of the total territory (47 thousand $\mathrm{km}^{2}$ ). That potential territories include the plains and foothills of the republic and are confined to oil and gas bearing basins-troughs that were intensively burried in the MesozoicCenozoic time (Fig. 1).

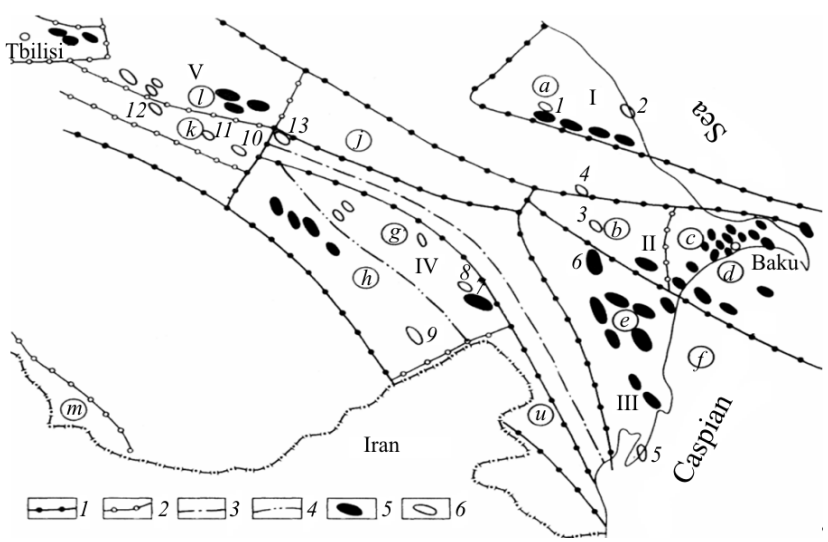

Fig. 1. Scheme of oil and gas bearing areas: $1-\mathrm{NGO}$ (I - Severo-Apsheronskaya, II - GobustanoApsheronskaya, III - Nizhnekurinskaya, IV - EvlakhAgdzhabedinskaya, V - Iori-Adzhinourskaya); 2 - NGR ( $a$ - Kusaro-Divichinskiy, $b$ - Shemakhino-Gobustanskiy, $c$ - Apsheronskiy, $d-$ Apsheronskiy archipelago, $e$ - Nizhnekurinskiy, $f-$ Bakinskiy archipelago, $g$ - Muradkhanlinskiy, Saatly-Geokchayskaya zone, $h$ - Kirovabadskiy, $i$ - Lenkoranskiy, $j$ - Adzhinourskiy, $k$ - interfluve of Kura and Iori rivers, $l$ - Mirzaanskiy, $m$ - Nakhichevanskiy, probably oil and gas bearing one); axial lines: 3 - Mingechaur-Saatly-Talyshskiy interbasin uplift, 4 - Evlakh-Agdzhabedinskiy trough; 5 - oil and gas fields; 6 - local uplifts: 1 - Talabi, 2 - Agzybirchala, 3 - Leninabad, 4 - Astrakhanovka, 5 - Kyzylagach, 6 - Kalamadyn, 7 - Muradkhanly, 8 - Zardob, 9 - Sovetlyar, 10 - Tarsdallyar, 11 - Gyurzundag, 12 - Sazhdag, 13 - Adzhinour)

However, despite more than a century of oil and gas production in Azerbaijan, the identified promising areas and zones are not the same in terms of the degree of study of hydrocarboncontaining deposits and resource estimates. So, in particular, if on the most studied Apsheron peninsula has exploration gedree of $2060 \mathrm{~m} / \mathrm{km}^{2}$ and 350 and $260 \mathrm{~m} / \mathrm{km}^{2}$ for the areas of Nizhnekurinskaya trough and PrikaspiyskoKubinskiy region respectively then in the central and western regions of the republic, particularly in the interfluve of the Kura and Iori and Azhinurskaya region, the subsoil has not been studied by deep drilling. Accordingly, that exploration degree is 7 and $3 \mathrm{~m} / \mathrm{km}^{2}$.

Considering such situation, during the last years drilling exploration works in the Republic have been moved from east regions to less studied central and west regions. Herewith, generalization of existing geological and geophysical data, estimation of the potential of individual lithologic and stratigraphic complexes and forecast of deep buried oil and gas reservoirs have critical importance.

\section{Geological features of the Kalamaddin area of the Prikurin intermontane depression}

Taking into account potential of oil and gas content of the Kura intermountain depression, presence within its borders of unexplored local uplifts, a possibility to explore oil and gas deposits of industrial importance in them, study of geological structure and reservoir properties of rocks of the Kalamaddin area are an urgent task in determination of potential structures and oil and gas bearing objects.

Due to oil and gas fields explored in the areas of Mishovdag, Galmaz, Kyurovdag and others in the Nizhnekurinskaya depression Kalamaddin area had become of the interest. Wild-cat wells started to be drilled on that area since 1967.

As a result, a sedimentary section of this area was studied from the Oligocene and Miocene (Maikop series $-\mathrm{P}_{3}-\mathrm{N}_{1}^{1}$ ) to quaternary deposits inclusive (see Fig. 1). There were sandy layers in the lower part of the Maikop deposits exposed and mainly clays in the upper part. The Chokrak formation that overlays the Maikop series is characterized by an alternation of thin sandstones and clays. An overlying diatom set is represented by clayish-sandy deposits.

Deposits of the productive strata (PS) (Lower Pliocene $-\mathrm{N}_{2}^{1}$ ) at the top of the dome are blurred and obtained in several wells. In terms of lithology they are represented by alternating clays and sands. Conglomerate layers are less common. A lower part of PS deposits (below around XI-IV layers) in the area of Kalamaddin is not presented. Eight sand layers are distinguished in the PS section and clay pack is located at the lower part. 
Deposits of the Akchagylskiy stage are found in several wells, they are blurred on the north-east wing of the fold. The Akchagylskiy deposits are lithologically represented by the alternation of gray, light gray clays, sand and sandstone. Interlayers of volcanic ash are presented in the lower part of the section.

Quaternary deposits occur mainly in the zones of immersion of the wings of the structure and are represented by alternating sand argillaceous rocks. The total thickness of the Akchagylskiy deposits is $450 \mathrm{~m}$.

Sediments of the Apsheronskiy stage are represented by three substages, lithologically expressed alternating sand, sandstone and clay. The lower substage has a minimum sand content. The middle Apsheron is more sandy. The Upper Apsheron is relatively clayish. The total thickness of the deposits of the Apsheron stage is $480 \mathrm{~m}$.

The Kalamaddin fold is a shortened brachyanticline that stretches from north-west to south-east. The length of the fold is $10-12 \mathrm{~km}$ and width is $4-5 \mathrm{~km}$. A south-west wing is steep $\left(30-80^{\circ}\right)$ while north-east wing is more gentle $\left(20-30^{\circ}\right)$. There is a regional deep fault along the longitudinal axis of the fold. The eastern wing of a fault is elevated. The amplitude is $1000 \mathrm{~m}$. There are two further longitudinal disorders in parallel. A middle block between them is 200-400 m higher than adjacent ones, which facilitated the formation of a graben along the axis. The fold is complicated by four more transverse ruptures (Fig. 2).

As it seen from the Fig. 3, development of the fold in general occurred gradually during geological time of interest. Obviously, that is caused by the fact that the fold is close to a source of compressive stresses, which is the Bolshekavkazskaya collision.

According to the studies carried out by geophysicists last years it is established that the fold consists of two independent domes, which are separated by a not clear anticline. The length of the northern dome in which the oil field is located is 6 $\mathrm{km}$, width is $2 \mathrm{~km}$ and altitude is $1.3 \mathrm{~km}$ (Fig. 4).

A mud volcano of Kalamaddin is associated with the above-mentioned first deep fault. A mud volcano, griffins, salsa as well as oil and gas appeared in the structural-exploration wells and favorable geological conditions provided the basis for deep exploration drilling to be started.

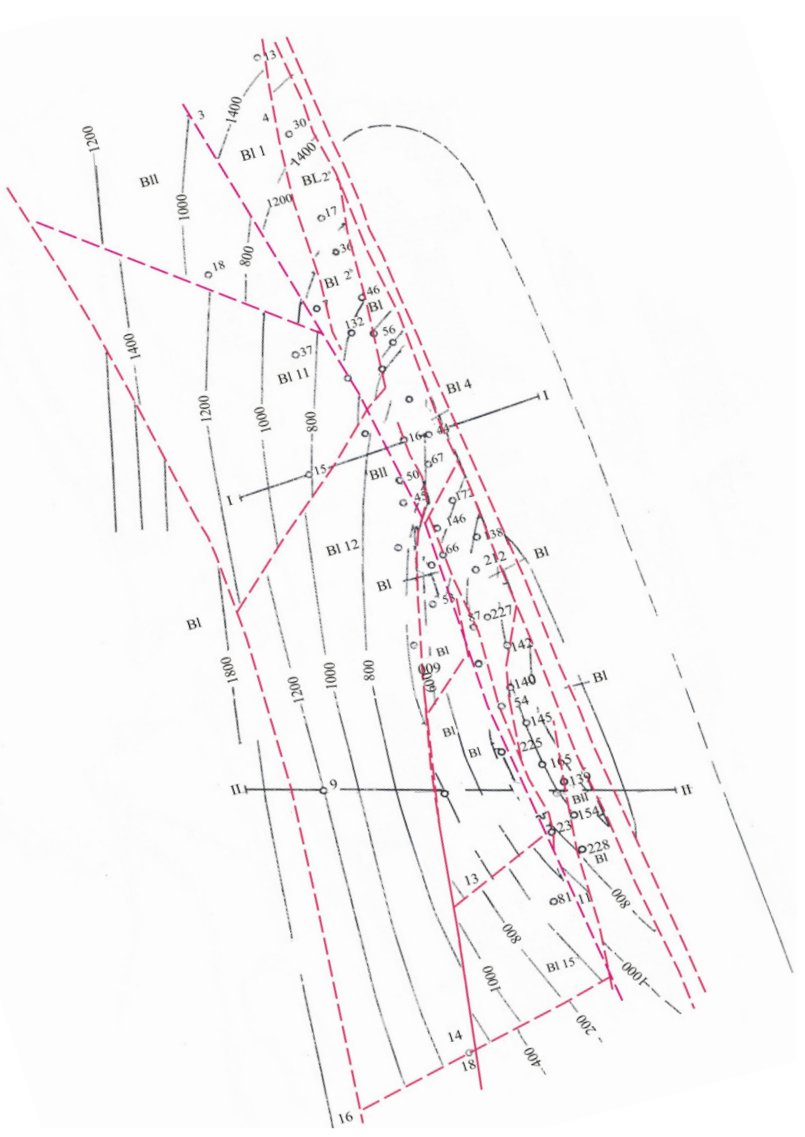

Fig. 2. Kalamaddin fold.

Structural map on the roof of IV formation of PS

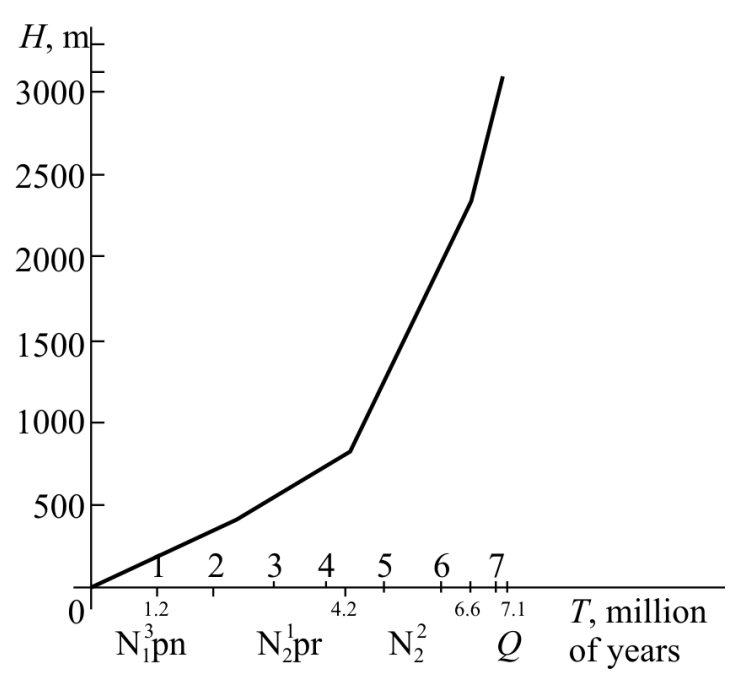

Fig. 3. Graph of Kalamaddin fold growth intensity

Determination of mud volcanoes' causes, griffins, salsas as well as oil content within the Kalamaddin uplift is possible using a fold development graph from the Pontic century to the present time. The Kalamaddin fold is the most north-western fold of the Kalamaddin-KhydyrliYanan Tava-Mugan-deniz anticlinal zone of the north-west-south-east stretch. The fold is located in 
the north-west of the Nizhnekurinskaya depression and extends within the Baku archipelago. It is seen on the graph that rate of development of the fold within the geological time under consideration is generally progressive (see Fig. 3). The fold began its development no later than in the Pontic century. The speed of development of the fold at this time is almost the same as the speed of development during early Pliocene. During late Pliocene the rate of development of the fold increased significantly. Then during Quaternary period it increased again. Such a growth pattern of the fold is associated with its location near to focus of compression stresses of collision of the Greater Caucasus. Intensive influence of the mechanisms of transverse and longitudinal bends during the Pliocene and Quaternary period especially influenced formation or activation of the mud volcano, which complicates it. That also influenced rejuvenation of ancient and appearence of new disturbances. Such active tectonic processes contributed to partial destruction and reformation of deposits. That state can be traced by the degree of oil and gas potential of natural reservoirs detected in a fold section.

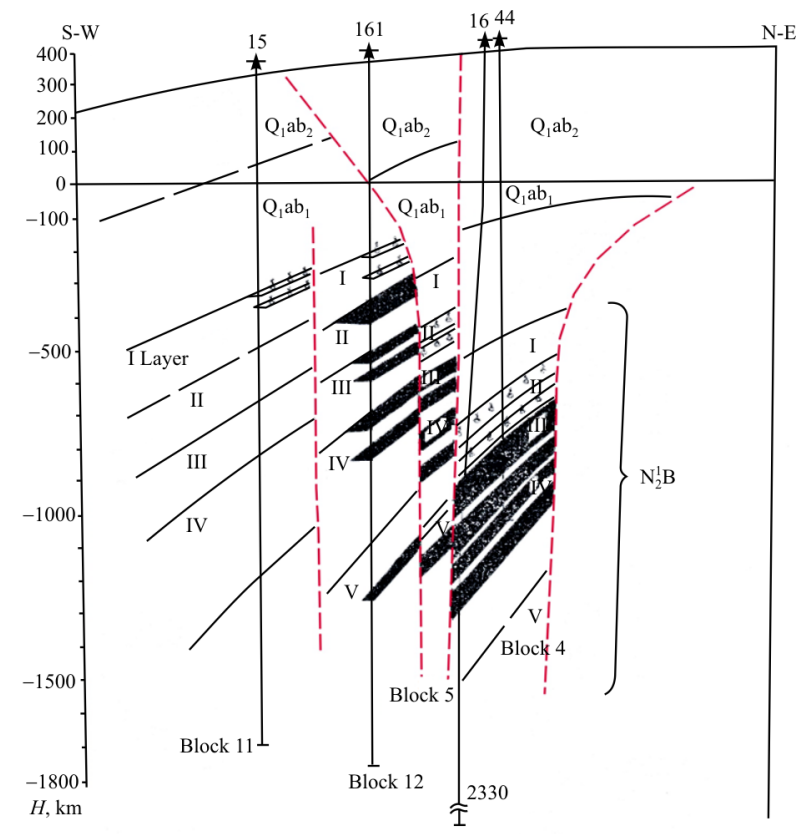

Fig. 4. Kalamaddin fold. Geological profile along the line I-I: $\mathrm{Q}_{1} \mathrm{ab}$ - Absheronskiy stage; $\mathrm{N}_{2}^{1} \mathrm{~B}-\mathrm{PS}$

Field discovery year is considered to be 1979 . Despite this fact first economicaly valuable oil inflow was obtained from upper and middle parts of the fold dome even before from the deposits of the Absheronskiy stage. Oil content of the V layer was obtained in 1979. Later in a short period of time, the oil and gas content of the IV, III, II and I layers was also found. Gas is obtained from the I level of a graben system of faults in the zone of a middle block. Layers II and III are oilbearing and gas-bearingin in some blocks (Fig. 5).

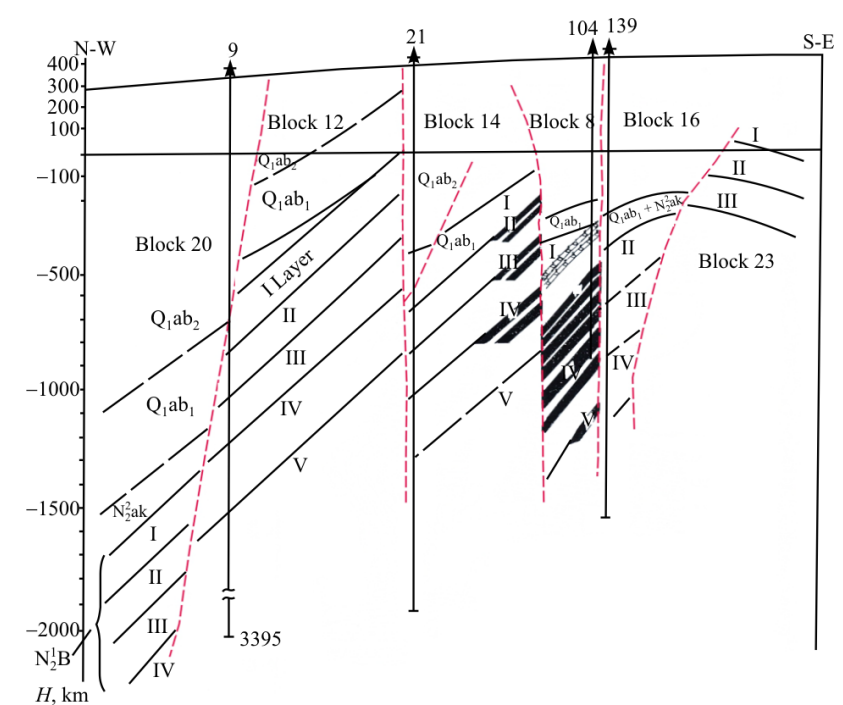

Fig. 5. Kalamaddin fold.

Geological profile along the line I-I

Layers IV and $\mathrm{V}$ are mainly oil-bearing. Flow rate of oil and gas wells varies in a wide range in different layers. For example, production rate in gas wells is 35-200 thousand $\mathrm{m}^{3} /$ day and 0.8-71 tonnes/day in oil wells [1-17].

\section{Change in reservoir properties of PS of the Kalamaddin field with depth}

In order to clarify prospects of the Kalamaddin oil field samples of core material taken from exploration and prospecting wells were studied. It should be noted that the Kalamaddin field was studied not enough compared to other areas of the Nizhnekurinskaya depression. As a result, in order to determine prospects of oil and gas it is necessary to study reservoir properties of the field deposits and surrounding areas.

To overcome this problem physical properties of samples that are as follows were studied: granulometric composition (\%), carbonate content $(\%)$, porosity $\left(K_{\mathrm{m}}, \%\right)$, density $\left(\sigma, \mathrm{g} / \mathrm{cm}^{3}\right)$, permeability $\left(10^{-15} \mathrm{~m}^{2}\right)$.

In particular, according to results of the study of granulometric composition of rocks in the productive strata of the Kalamaddin oil field, it was established that the grain sizes vary in the range of 0.1-0.01 mm. This indicates a predominance of aleurite in a section. Some grain size dynamics (with a gradual increase) is caused by the uneven distribution of lithotypes in a section. 
A regular change in values of physical properties of rocks in lithostratigraphic units has also been established. Those properties participate in geological structure formation in terms of area and section. To do that the range of variation and mean reservoir properties of the layers were calculated. In addition, dependences of permeability on porosity, porosity on depth and changes in other physical parameters with depth were determined. Limits of change and mean values of petrophysical properties of a PS rock along the section are tabulated and graphically presented in Fig. 6.

Change in petrophysical properties of deposits of Kalamaddin PS with depth

\begin{tabular}{|c|c|c|c|c|c|c|}
\hline \multirow{3}{*}{ Interval, m } & \multicolumn{3}{|c|}{$\begin{array}{l}\text { Granulometric composition, \% } \\
\text { fractions, mm }\end{array}$} & \multirow{3}{*}{$\begin{array}{l}\text { Carbonate } \\
\text { content, } \%\end{array}$} & \multirow{3}{*}{ Porosity, \% } & \multirow{3}{*}{$\begin{array}{l}\text { Permeability } \\
10^{-15} \mathrm{~m}^{2}\end{array}$} \\
\hline & psammite & siltstone & clays & & & \\
\hline & $>0.25-0.1$ & $0.1-0.01$ & $<0.01$ & & & \\
\hline 4 & 6 & 7 & 8 & 9 & 10 & 11 \\
\hline $324-420$ & $\frac{31.7-55.7}{43.7(2)}$ & $\frac{32.8-48.7}{40.8(2)}$ & $\frac{9.3-17.8}{13.6(2)}$ & $\frac{12.0-13.5}{12.5(2)}$ & $\frac{21.3-36.2}{28.8(2)}$ & $\frac{217.0-907.0}{562.0(1)}$ \\
\hline $421-510$ & $\frac{21.4-53.7}{36.5(9)}$ & $\frac{29.7-53.2}{39.7(9)}$ & $\frac{12.2-48.6}{23.1(9)}$ & $\frac{11.0-17.0}{14.5(4)}$ & $\frac{25.0-35.0}{28.3(9)}$ & $\frac{72.0-1457.0}{670.2(9)}$ \\
\hline $510-855$ & $\frac{0.1-0.3}{0.2(4)}$ & $\frac{34.3-53.8}{42.7(4)}$ & $\frac{46.0-65.5}{57.4(4)}$ & $\frac{9.9-37.4}{17.4(6)}$ & $\frac{5.7-26.2}{18.3(6)}$ & $\frac{0.001-18.3}{7.3(6)}$ \\
\hline 865-900 & $\frac{19.2-49.6}{34.4(2)}$ & $\frac{30.5-61.2}{45.85(2)}$ & $\frac{19.5-19.5}{19.5(2)}$ & $\frac{5.8-10.3}{8.05(2)}$ & $\frac{20.1-22.9}{21.5(2)}$ & $\frac{49.0-75.0}{60.0(2)}$ \\
\hline $905-1050$ & $\frac{0.1-22.1}{8.9(13)}$ & $\frac{31.1-55.5}{40.1(13)}$ & $\frac{40.9-68.8}{41.1(13)}$ & $\frac{9.9-24.9}{14.3(15)}$ & $\frac{8.4-21.5}{17.2(15)}$ & $\frac{0.001-294.0}{83.1(15)}$ \\
\hline $1060-1210$ & $\frac{2.0-21.2}{21.3(6)}$ & $\frac{31.0-50.1}{38.5(6)}$ & $\frac{40.8-52.3}{46.2(6)}$ & $\frac{9.4-21.0}{14.1(13)}$ & $\frac{4.6-22.3}{16.8(13)}$ & $\frac{0.001-28.1}{33.2(13)}$ \\
\hline $1215-1250$ & $\frac{0.2-27.3}{10.3(15)}$ & $\frac{22.1-61.6}{41.8(15)}$ & $\frac{33.3-61.1}{48.3(15)}$ & $\frac{6.6-38.9}{13.1(16)}$ & $\frac{11.1-22.1}{15.6(16)}$ & $\frac{0.4-125.0}{33.3(16)}$ \\
\hline $1255-1400$ & $\frac{0.1-24.7}{17.2(3)}$ & $\frac{29.8-43.8}{33.3(3)}$ & $\frac{41.6-45.9}{43.2(3)}$ & $\frac{15.5-27.0}{20.1(4)}$ & $\frac{6.1-21.3}{14.2(4)}$ & $\frac{0.2-105.0}{32.4(4)}$ \\
\hline $2310-2650$ & $\frac{0.3-31.6}{7.2(14)}$ & $\frac{18.2-66.6}{44.3(14)}$ & $\frac{25.5-78.9}{48.4(14)}$ & $\frac{6.1-30.1}{15.6(15)}$ & $\frac{4.4-27.4}{13.3(15)}$ & $\frac{0.001-99.1}{8.5(15)}$ \\
\hline $2650-2929$ & $\frac{2.0-21.2}{8.3(6)}$ & $\frac{31.0-50.1}{42.7(6)}$ & $\frac{40.8-52.3}{50.2(6)}$ & $\frac{9.4-21.0}{15.1(13)}$ & $\frac{4.6-22.3}{11.8(13)}$ & $\frac{0.001-28.1}{3.2(13)}$ \\
\hline
\end{tabular}

$\mathrm{N}$ o t e. There are extreme values indicated in the numerator, mean values indicated in the denominator and the number of samples examined in brackets.

\begin{tabular}{|c|c|c|c|c|c|c|}
\hline \multirow{2}{*}{ Interval, $\mathrm{m}$} & \multicolumn{3}{|c|}{$\begin{array}{c}\text { Granulometric composition, \% } \\
\text { fractions, } \mathrm{mm}\end{array}$} & $\begin{array}{c}\text { Carbonate } \\
\text { content, } \%\end{array}$ & Porosity, \% & $\begin{array}{c}\text { Permeability, } 10^{-15} \\
\mathrm{~m}^{2}\end{array}$ \\
\hline 4 & $>0.25-0.1$ & $0.1-0.01$ & $<0.01$ & \\
\hline $324-420$ & 6 & 7 & 8 & 9 \\
\hline $421-510$ & &
\end{tabular}

Fig. 6. Graph of change in petrophysical properties of rocks of Kalamaddin PS with depth 
As it seen from the graphs shown in Fig. 6 the reservoir properties of rocks deteriorate with depth. Such decrease in porosity with depth is caused by changing granulometric composition of rocks with time. That dependence is more visible on the mean values of petrophysical properties of the rocks.

An analysis of depth intervals of variation of porosity and clayiness values shows that porosity of rocks decreases with depth from 28.8 to $11.8 \%$. On contary, clay content increases with depth from 13.6 to $50.2 \%$ (see Table and Fig. 6). Doubtless, reservoir properties of rocks are also affected by content of other fractions, degree of sorting, carbon content, compactness etc. Moreover, it is notably that according to data of shallow and deep wells change in reservoir properties of rocks occures at individual tectonic blocks as well. The last, in our opinion, is connected to the genetic nature of the fold itself, degree of its complexity by disjunctives, their types, hypsometric position of tectonic blocks, relative to each other, and the degree of development of compressive or tensile stresses within individual tectonic blocks, as well as with a number of other factors. Above mentioned processes are also occur in deep zones. That allows to predict there are porous oil and gas reservoirs in the lower deep parts of field sections. In addition, it can be seen from the graph of change in granulometric and reservoir properties (see Fig. 5) that there is a definite relationship between reservoir properties and granulometric composition of rocks. For example, an amount of psammitic and silty facies at the of interval of $324-510 \mathrm{~m}$ is $64.5-76.2 \%$ and $13.6-23 \%$ for pellite facies. Porosity is 28.8-28.3\%, permeability is $(562.0 \ldots 670.0) 10^{-15} \mathrm{~m}^{2}$. Then amount of psammitic facies is $0.2-34.4 \%$ at the interval of $510-900 \mathrm{~m}, 42.7-45.7 \%$ for siltstone, $57.4-19.5 \%$ for pellite, porosity is $18.3-21.5 \%$, permeability is just $(7.3 \ldots 60.0) 10^{-15} \mathrm{~m}^{2}$. Low permeability $\left(7.3 \cdot 10^{-15} \mathrm{~m}^{2}\right)$ at this interval is connected to granulometric composition of rocks. As it is seen from the table and Fig. 6 granulometric composition of the rock at the interval of $510-855 \mathrm{~m}$ consits of clays $(37.4 \%)$, siltstones $(42.7 \%)$ and coarse-grained sands (only $0.2 \%$ ). Such a granulometric composition has subcapillary or close to it rock porosity. For this reason, permeability in this type of rocks is very low. Such rocks have relatively high carbon content that acts as a cement and lead to a decrease in permeability.

There is a strong decrease in carbonate and clay content at depth interval of $865-900 \mathrm{~m}$. At the same time, sand content in siltstones is increased from 34.4 to $45.9 \%$ and permeability is increased (up to $60.0 \cdot 10^{-15} \mathrm{~m}^{2}$ ) relative to an overlying depth interval.

The reason for these changes in the considered interval is associated with a sharp decrease in clay and sand content. However, an increase in siltstones to $45.9 \%$ caused a slight increase in porosity and permeability (see Fig. 6) due to the good mutual packing of sands and siltstones.

There is a sharp decrease in sand content up to $8.9 \%$ at the interval of $905-1050 \mathrm{~m}$, an increase in clay content by more than two times $(41.1 \%)$ and a slight increase in carbonate content. Despite the fact that such ratio of fractions caused a relative decrease in porosity, a slight increase in permeability is observed.

A sharp change in the percentage ratio of rock fractions at the depth interval of $1060-2310 \mathrm{~m}$ is not observed. Thus, sand fraction varies in the range of 21.3-17.2 \%, siltstones - 38.5-33.3 \% and clays - 46.2-43.2\%. Carbonate content increases with depth from 14.1 to $20.1 \%$. Having such a relatively weak variability of the lithofacial composition of the section, porosity decreases from 16.8 to $14.2 \%$. Permeability at this depth interval, in comparison with the previous ones, is twice less and remains almost stable $\left((33.2 \ldots 32.4) 10^{-15} \mathrm{~m}^{2}\right)$. Permeability values are less than standart at the interval of interest and related to the content of siltstones and, in particular, to clays in the fractional rock composition.

At the interval of $2310-2929 \mathrm{~m}$ the sand content decreases sharply (8.3-7.2\%), content of siltstones and clays is 42.7-44.3 and 48.4-50.2\%, carbonate content is $15.1-15.6 \%$. Despite the fact that for that lithological composition porosity of rocks is $13.3 \%$, it is possible to say that they are impermeable $\left((8.5 \ldots 3.2) 10^{-15} \mathrm{~m}^{2}\right)$.

In general, results of the studies show that in the considered depth interval in the normal lithologic and stratigraphic section of the Kalamaddin area permeability of rocks is directly proportional to their sand content and inversely proportional to their clay content. 
Analysis of rock petrophysical data and plotting the change in their values allowed to understand that in some cases regularity of change in petrophysical data is disturbed. To clarify such a phenomenon core materials were studied under conditions of high temperature and pressure.

These rocks are exposed to stresses arising from mechanical, physical and chemical processes under natural conditions in deep layers of the earth. In particular, rocks that are on the epigenesis stage being under the influence of pressure and temperature experience dissolution of mineral substances and change in pore space.

During the well drilling extracted rock samples (cores) are subjected to elastic deformation. Study of these cores allows to obtain detailed information about physical and reservoir properties of rocks in accordance with depth of their occurrence. So, study of elastic and reservoir properties of rocks under thermobaric conditions is on the front burner in the development of oil and gas fields.

Studies show that as a result of geological and physical processes physical properties of the rocks that have the same name and age change and acquire different values. These conclusions are confirmed by studies conducted under high pressure and temperature, i.e. when rocks are burried in conditions of great depths. However, productive reservoirs are porous media saturated with liquid and gas. So, porosity affects the physical properties of rocks. That means it is also necessary to take into account intraporous pressure during the research. Influence of pore pressures on the speed of elastic waves in silty and tuffite rocks, whose porosity is $20 \%$, was studied. It was found for those samples that initial speed was slightly decreased and then increased back.

A detailed study of porosity and density of rocks under high pressure showed that these parameters are subject to a significant change. All these indicators are taken into account in the study of geological and geophysical materials. In the pressure range $0-60 \mathrm{MPa}$ (that corresponds to a depth of 5-6 km), elastic deformations of the pore space are $30-50 \%$.

One of the features of sandstones and aleurites is the change in porosity depending on the pressure. At pressure of $20-30 \mathrm{MPa}$ the ratio $\Delta K / K_{\mathrm{p}}$ (relative change in porosity coefficient) has a maximum gradient. Then, the gradient decreases and reaches zero at pressure above $60 \mathrm{MPa}$.
Clayish sandstones and siltstones with high initial porosity have minimum relative change in the porosity coefficient. If the reason of maximum relative change for very clayish rocks that have low initial porosity are reveiled, then it will be possible to determine the change in reservoir properties of rocks with depth, i.e. identify the reasons for their decrease or increase.

However, as the clayiness in sand reservoirs decreases and the grain sizes increase, their reservoir properties are improved. In that regard, relatively low change in the porosity coefficient is observed for porous rocks $\left(K_{\mathrm{p}}\right)$.

The most important factors in the change of porosity of rocks under pressure are composition of cement and a cementation type. There is a minimal change observed when an amount of cement is constant. There is a small change observed in sandy rocks for carbonatetype cement. Porosity for clayish rocks increases depending on pressure. Porosity of basal-pore type of cement being under the pressure increases even more.

It is possible to evaluate the effect of elastic density variation in rocks on the change in the porosity value. Maximum density change for sandy and siltstone rocks is $1-2 \%$.

It is known that change in velocity of propagation of elastic waves in all rocks at pressures up to $60 \mathrm{MPa}$ is qualitatively the same. Pressure increase causes increase in velocity, which rises until the pressure of $40 \mathrm{MPa}$. Propagation velocity of the waves changes gradually until the pressure of $30 \mathrm{MPa}$, then at $40 \mathrm{MPa}$ destruction is observed. If the effective pressure is $60 \mathrm{MPa}$ then relative change in the propagation of the wave velocity varies in the range of 5-10\%. Similar changes in sandstones and siltstones make up $10 \%, 9 \%$ in limestones and marls, $8 \%$ in tuffites and up to $7 \%$ in andesites and porphyrites.

Study of the effect of high pressure on the velocity of an elastic wave in sandstones, siltstones, marls, limestones, volcanogenic rocks and resulting relationship between velocity and porosity show that their relationship undergoes a significant change depending on pressure magnitude. Based on that, it is expedient to apply data that correspond to the conditions of occurrence of rocks while using the relationship between velocity and porosity. 
Comparison of the relative change in velocity and porosity in different pressure ranges for 20 samples of the same type showed that the role of porosity coefficient $\left(K_{\mathrm{p}}\right)$ varies under different conditions of rock strength.

According to data in the table and Fig. 6 changes in granulometric composition and carbonate content of rocks have a direct effect on their reservoir properties. In particular, for the depth interval of 324-420 m having rock grain size composition of $43.7 \%$ of psammites, $40.8 \%$ of siltstones and $13.6 \%$ of pelites, carbonate content of $12.5 \%$, porosity is $28.8 \%$ and permeability is $562.0 \cdot 10^{-15} \mu^{2}$. In turn, in the depth interval $421-$ $510 \mathrm{~m}$ with a granulometric composition of rocks of $36.5 \%$ psammites, $39.7 \%$ siltstones and $23.1 \%$ pelites with a carbonate content of $14.5 \%$ porosity and permeability were $28.3 \%$ and $670.2 \cdot 10^{-15} \mu \mathrm{m}^{2}$ respestively. In other words, according to the data given, the rocks of the upper deep floor should have greater permeability. However, the higher permeability of the rocks of the second depth interval is observed due to relatively large pore sizes or the prevalence of volume of open pores.

Content of rocks that burried at the depth interval of $510-855 \mathrm{~m}$ include $0.2 \%$ of psammites, $42.7 \%$ of siltstones and $57.4 \%$ of pelites and carbonate content of $17.4 \%$, porosity is $18.3 \%$, permeability is just $7.3 \cdot 10^{-15} \mu \mathrm{m}^{2}$.

At the interval of depths of $865-900$ m rocks consist of $34.4 \%$ of psammites, $45.85 \%$ of aleurites and $19.5 \%$ of pelites with a carbonate content of $8.05 \%$. But the porosity here is $21.5 \%$, permeability is $60.0 \cdot 10^{-15} \mu \mathrm{m}^{2}$. Relative increase in permeability up to $60.0 \cdot 10^{-15} \mu^{2}$ and significant decrease in the carbonate and clay content of the section is explained by the multiple increase in psammites. Relative increase in permeability up to $60.0 \cdot 10^{-15} \mu^{2}$.

At the interval of $905-1050 \mathrm{~m}$ the content of psammitic fraction sharply drops to $8.9 \%$ against the background of significant increase in the pelite fraction and slight decrease in the fraction of siltstones down to $10.40 \%$ and an increase of carbonate content up to $14.3 \%$. Such a fractional composition results in a decrease in porosity down to $17.2 \%$ with a slight increase in permeability to $83.1 \cdot 10^{-15} \mu \mathrm{m}^{2}$. As it seen, a sharp decrease in the psammitic fraction with a simultaneous increase in clayiness contributed to decrease in porosity. However, an increase increase in permeability may also be due to the appearance of secondary porosity.

At the depth interval of 1060-1210 m rocks are composed of $21.3 \%$ psammites, $38.5 \%$ of siltstones, $46.2 \%$ of pelites with carbonate content of $14.1 \%$, porosity is $16.8 \%$, permeability has decreased to $33.2 \cdot 10^{-15} \mu^{2}$. According to the given values, in comparison with the previous depth interval psammites increased twice and pelite fractionand increased by $5 \%$. Decrease in permeability is associated with poor sorting of fractions, as well as partial blockage of open pores due to increase in content of pelite fraction.

At the depth interval of 1215-1250 m rocks are characterized by a double decrease in the content of psammites and relatively small increase in the fraction of siltstones and pellites with a decrease in carbonate content and porosity by only $1 \%$ compared to the previous interval. At the same time, permeability kept the same as at the depth interval of 1016-1240 m apparently for the same reason.

The depth interval 1255-1400 $\mathrm{m}$ is characterized by increase in a psammitic fraction from 10.3 to $17.2 \%$ with decrease in the fractions of siltstones and pellites to 33.3 and $43.2 \%$ respectively against the background of increase in carbonate content to $20.1 \%$. Having such rock composition, their porosity decreased to $14.2 \%$. Actual deterioration of sorting of the granulometric composition led to a slight decrease in permeability of rocks at this interval, which was $32.4 \cdot 10^{-15} \mu \mathrm{m}^{2}$. Rocks from the depth intervals 2310-2650 and $2650-2929 \mathrm{~m}$ characterized by a decrease in the psammitic fraction below $9 \%$, increase of siltstones to $44.3-42.7 \%$, pellic fraction up to 48.4-50.2 \% with carbonate content up to 15.6-15.1 \%. Such facies composition and mentioned carbonate content with porosity of $14.3-11.8 \%$ characterize rocks with permeability of $8.5-3.2 \cdot 10^{-15} \mu \mathrm{m}^{2}$, i.e. rocks with almost no permeability. That is caused by the high content of pellites and siltstones with a relatively low value of the psammitic fraction [18-33].

\section{Conclusion}

A summary of the studies conducted allow to say, that the change in reservoir properties of rocks over a wide range of Kalamaddin area is caused by lithological heterogeneity of rock complexes, variety of depth of their bedding, difference in 
pressures, temperatures and complexity of tectonic conditions.

Results of various petrophysical methods of research show that reservoir properties of rocks generally deteriorate with depth. However, in some cases in clay and carbonate rocks reservoir properties can be improved due to the appearance of secondary porosity at relatively tough pressures and temperatures. In order to predict oil and gas content of deep burried layers along with methods of exploration geophysics, the data on reservoir properties of a formation should also be used.

\section{References}

1. Ali-zade A.A., Akhmedov G.A., Akhmedov A.M., Aliev A.K., Zeinalov M.M. Geologiia neftianykh i gazovykh mestorozhdenii Azerbaidzhana [Geology of oil and gas fields of Azerbaijan]. Moscow, Nedra, 1966,390 p.

2. Iusifzade Kh.B. Primenenie sovremennykh tekhnologii v oblasti razvedki i dobychi neftegazovykh mestorozhdenii v Azerbaidzhane [Application of modern technologies in the field of exploration and production of oil and gas fields in Azerbaijan]. Zhurnal ANKh, 2013, no.7-8, pp.3-13.

3. Hasanov A.B., Balakishibayli Sh.A. The influence of recent geodynamics on the physicomechanical state of the geological environment of the sedimentary cover. Evaluation of synthetic elastic parameters of reservoirs, fluid phase saturation and temperatures in the depths. Materials of international workshop. Baku, 2010, pp.101-108.

4. Gadirov V.G. Magmaticheskii vulkanizm srednekurinskoi vpadiny Azerbaidzhana i ego rol' v skoplenii uglevodorodov [Magmatic volcanism in the Middle Kur depression of Azerbaijan and its role in hydrocarbon accumulations], available at: http://sinp.com.ua/work/ 679254/Magmaticheskij-vulkanizmSrednekurinskoj-vpadiny (accessed 12 January 2017).

5. Kerimov K.M., Rakhmanov R.R., Kheirov M.B. Neftegazonosnost' Iuzhno-Kaspiiskoi megavpadiny [Oil and gas potential of the South Caspian megacut]. Baku, 2001,317 p.

6. Khain V.E. Tektonika neftegazonosnykh oblastei Iugo-Vostochnogo pogruzheniia Bol'shogo Kavkaza [Tectonics of oil-and-gas bearing regions of the SouthEastern immersion of the Great Caucasus]. Moscow, Gostoptekhizdat, 1958, 224 p.

7. Spravochnik po litologii [Reference book on lithology]. Ed. N.B. Vassoevich. Moscow, 1988, 509 p.

8. Spravochnik po geologii nefti i gaza [Reference book of oil and gas geology]. Moscow, Nedra, 1988, 480 p.

9. Babazade B.Kh., Putkaradze L.A. O poiskakh zalezhei gaza i nefti $\mathrm{v}$ pribrezhnoi morskoi zone Apsheronskogo poluostrova i Bakinskogo arkhipelaga [On the search for gas and oil deposits in the coastal marine zone of the Absheron Peninsula and the Baku Archipelago]. Geologiia nefti $i$ gaza, 1961, no.10, pp.7-11.

10. Sokolov B.A. Evoliutsiia i neftegazonosnost' osadochnykh basseinov [Evolution and petroleum potential of sedimentary basins]. Moscow, Nauka, 1980, 243 p.

11. Uspenskaia N.Iu., Tauson N.N. Neftegazonosnye provintsii i oblasti zarubezhnykh stran [Oil and gas provinces and regions of foreign countries]. Moscow, Nedra, 1972, 283 p.

12. Ali-Zade A.A., Salaev S.G., Aliev A.I. Nauchnaia otsenka perspektiv neftegazonosnosti Azerbaidzhana i Iuzhnogo Kaspiia i napravlenie poiskovo-razvedochnykh rabot [Scientific assessment of the prospects of oil and gas potential of Azerbaijan and the South Caspian and the direction of prospecting works]. Baku, Elm, 1985, 227 p.

13. Landolt-Bornstein tables. Physical properties of rocks, subvolume B. Ed. G. Angenheister. N.Y., 1983. DOI: $10.1007 / \mathrm{b} 20009$

14. Theoretical and experimental investigations of physical properties of rocks and minerals under extreme p,T-conditions. Berlin, Academie Verlag, 1979, 232 p.

15. Afandiyeva M.A., Guliyev I.S. Maicop Groupshale hydrocarbon complex in Azerbaijan. 75th EAGE Conference \& Exhibition incorporating SPE EUROPEC, 2013, pp. 06-13. DOI: 10.3997/2214-4609.20130979

16. Salmanov A.M., Suleimanov A.M., Magerramov B.I. Paleogeologiia neftegazonosnykh raionov Azerbaidzhana [Paleogeology of oil and gas bearing regions of Azerbaijan]. Baku, 2015, 470 p.

17. Kerimov K.M. Glubinnoe stroenie i neftegazonosnost' depressionnykh zon Azerbaidzhana i Iuzhnogo Kaspiia [Deep structure and oil and gas potential of the depression zones of Azerbaijan and the Southern Caspian]. Baku, $2009,440 \mathrm{p}$.

18. Fizicheskie svoistva gornykh porod i poleznykh iskopaemykh [Physical properties of rocks and minerals]. Ed. N.B. Dortman. Moscow, Nedra, 1976, 527 p.

19. Volarovich M.P., Baiuk E.I., Efimova G.A. Uprugie svoistva mineralov pri vysokikh davleniiakh [Elastic properties of minerals at high pressures]. Moscow, Nauka, 1975, 130 p.

20. Gurbanov V.Sh., Narimanov N.R., Sultanov L.A., Babaev M.S. Geologicheskoe stroenie i kollektorskie svoistva mezokainozoiskikh otlozhenii DzharlySaatlinskogo neftegazonosnogo raiona na bol'shikh glubinakh [Geological structure and reservoir properties of the Mesozoic-Cenozoic deposits of the Jarly-Saatli oil and gas bearing region at great depths]. Izvestiia Ural'skogo gosudarstvennogo gornogo universiteta, 2016, no.2(42), pp.25-27. DOI: 10.21440/2307-2091-2016-2-25-27

21. Gurbanov V.Sh., Sultanov L.A. On oil-and-gas content of Mesozoic deposits in Azerbaijan. Bulletin of Perm National Research Polytechnic University. Geology. Oil \& Gas Engineering \& Mining, 2015, no.16, pp.7-13. DOI: 10.15593/2224-9923/2015.16.1

22. Sostavlenie kataloga kollektorskikh svoistv mezokainozoiskikh otlozhenii mestorozhdenii nefti-gaza i perspektivnykh struktur Azerbaidzhana [Compilation of the catalog of reservoir properties of the Mesozoic-Cenozoic deposits of oil and gas fields and perspective structures of Azerbaijan]. Otchet Nauchno-issledovatel'skogo instituta geofiziki 105-2009. Baku, 2010. 
23. Babaev M.S., Sultanov L.A., Ganbarova Sh.A., Alieva T.A. O rezul'tatakh petrofizicheskikh issledovanii otlozhenii produktivnoi tolshchi neftegazonosnykh ploshchadei Bakinskogo arkhipelaga [On the results of petrophysical studies of deposits of the productive sequence of oil and gas areas of the Baku Archipelago]. Izvestiia vysshikh tekhnicheskikh uchebnykh zavedenii Azerbaidzhana, 2014, no.2, pp.7-12.

24. Gurbanov V.Sh., Sultanov L.A., Abbasova G.G. Litologo-petrograficheskie i kollektorskie svoistva mezokainozoiskikh otlozhenii Prikaspiisko-Gubinskogo neftegazonosnogo raiona [Lithological, petrographic and reservoir properties of the Mesozoic-Cenozoic deposits of the Caspian-Guba oil and gas bearing region]. Geofizicheskie novosti Azerbaidzhana, 2014, no.3-4, pp.10-13.

25. Sultanov L.A., Nadzhaf-Kuieva V.M., Abbasova G.G. O zakonomernosti raspredeleniia skorosti prodol'nykh voln i plotnosti osadochnykh porod PrikaspiiskoKubinskoi oblasti i mezhdurech'ia Kury i Gabyrry [On the regularity of the velocity distribution of longitudinal waves and the density of sedimentary rocks of the Caspian-Cuban region and the interfluve of the Kura and Gabirry rivers]. XX Gubkinskie chteniia. Tezisy dokladov. Moscow, 2013.

26. Gurbanov V.Sh., Babaev M.S., Sultanov L.A., Rustamova R.E. Kratkaia geologo-geofizicheskaia kharakteristika razreza zemnoi kory raiona Saatlinskoi sverkhglubokoi skvazhiny SG-1 [Brief geological and geophysical characteristics of the crustal section of the Saatlinskaya superdeep well area SG-1]. Azerbaidzhan geologu, 2012, no.16, pp.31-37.

27. Physical properties of the mineral system of the Earth's interior. International monograph Project 3 CAPG. Praha, 1985, $564 \mathrm{p}$.

28. Lebedev T.S. Model studies of physical properties of mineral matter in high pressure - temperature experiments. Phys. Earth and Planet. Inter., 1980, vol.25, p.292-303. DOI:10.1016/0031-9201(80)90126-0

29. Rakhmanov R.R. Zakonomernosti formirovaniia i razmeshcheniia zon neftegazonakopleniia $\mathrm{v}$ mezozoiskikh otlozheniiakh Azerbaidzhana [Regularities in the formation and location of oil and gas accumulation zones in the Mesozoic deposits of Azerbaijan]. Baku, Elm, $1985,108 \mathrm{p}$.

30. Kozhevnikov D.A. Petrofizicheskaia invariantnost' granuliarnykh kollektorov [Petrophysical invariance of granular reservoirs]. Geofizika, 2001, no.4, pp.31-37.

31. Rachinskii M.Z., Chilingar Dzh. Rezul'taty geologorazvedochnykh rabot 1990-2005 gg., geologicheskie aspekty perspektiv i kolichestvennaia otsenka [Results of geological exploration work in 1990-2005, geological aspects of prospects and quantitative assessment]. Zhurnal ANKh, 2007, no.1, pp.7-15.

32 Mekhtiev U.Sh., Kheirov M.B. Litologopetrograficheskie osobennosti i kollektorskie svoistva porod kalinskoi i podkirmakinskoi svit Apsheronskoi neftegazonosnoi oblasti Azerbaidzhana [Lithological and petrographic features and reservoir properties of the rocks of the Kalin and Podkirmakinsky suites of the Absheron oil and gas region of Azerbaijan]. Baku, 2007, part 1, 238 p.

33. Rakhmanov R.R., Sultanov L.A., NadzhafKulieva V.M., Ganbarova Sh.A. Otsenka perspektiv neftegazonosnosti produktivnykh tolshch nizhnego pliotsena melkovodnoi zony Apsheronskogo poluostrova i Bakinskogo arkhipelaga po kompleksnym dannym geologogeofizicheskikh issledovanii [Estimation of oil and gas potential prospects of the productive sequences of the Lower Pliocene of the shallow zone of the Absheron Peninsula and the Baku Archipelago based on complex data of geological and geophysical studies]. Materialy mezhdunarodnogo seminara. Ukhta, 2013.

\section{Библиографический список}

1. Геология нефтяных и газовых месторождений Азербайджана / А.А. Али-заде, Г.А. Ахмедов, А.М. Ахмедов, А.К. Алиев, М.М. Зейналов. - М.: Недра, 1966. - 390 с.

2. Юсифзаде Х.Б. Применение современных технологий в области разведки и добычи нефтегазовых месторождений в Азербайджане // Журнал АНХ. - 2013. - № 7-8. - С. 3-13.

3. Hasanov A.B., Balakishibayli Sh.A. The influence of recent geodynamics on the physicomechanical state of the geological environment of the sedimentary cover // Evaluation of synthetic elastic parameters of reservoirs, fluid phase saturation and temperatures in the depths: materials of international workshop. - Baku, 2010. P. 101-108.

4. Гадиров В.Г. Магматический вулканизм среднекуринской впадины Азербайджана и его роль в скоплении углеводородов [Электронный ресурс]. URL: http://sinp.com.ua/work/679254/Magmaticheskijvulkanizm-Srednekurinskoj-vpadiny (дата обращения: 12.01.2017).
5 Керимов К.М., Рахманов Р.Р., Хеиров М.Б. Нефтегазоносность Южно-Каспийской мегавпадины. Баку, 2001. - 317 c.

6. Хаин В.Е. Тектоника нефтегазоносных областей Юго-Восточного погружения Большого Кавказа. - М.: Гостоптехиздат, 1958. - 224 c.

7. Справочник по литологии / под ред. Н.Б. Вассоевича. - М., 1988. -509 с.

8. Справочник по геологии нефти и газа. - М.: Недра, 1988. - 480 с.

9. Бабазаде Б.Х., Путкарадзе Л.А. О поисках залежей газа и нефти в прибрежной морской зоне Апшеронского полуострова и Бакинского архипелага // Геология нефти и газа. - 1961. - № 10. - С. 7-11.

10. Соколов Б.А. Эволюция и нефтегазоносность осадочных бассейнов. - М.: Наука, 1980. - 243 с.

11. Успенская Н.Ю., Таусон Н.Н. Нефтегазоносные провинции и области зарубежных стран. - М.: Недра, 1972. $-283 \mathrm{c}$.

12. Али-Заде А.А., Салаев С.Г., Алиев А.И. Научная оценка перспектив нефтегазоносности Азербайджана 
и Южного Каспия и направление поисково-разведочных работ. - Баку: Элм, 1985. - 227 с.

13. Landolt-Bornstein tables. Physical properties of rocks, subvolume B / ed. G. Angenheister. - N.Y., 1983. DOI: $10.1007 / \mathrm{b} 20009$

14. Theoretical and experimental investigations of physical properties of rocks and minerals under extreme p,T-conditions. - Berlin: Academie Verlag, 1979. $232 \mathrm{p}$.

15. Afandiyeva M.A., Guliyev I.S. Maicop Groupshale hydrocarbon complex in Azerbaijan // 75th EAGE Conference \& Exhibition incorporating SPE EUROPEC. - London, 2013. - P. 06-13. DOI: $10.3997 / 2214-4609.20130979$

16. Салманов А.М., Сулейманов А.М., Магеррамов Б.И. Палеогеология нефтегазоносных районов Азербайджана. Баку, 2015. - 470 с.

17. Керимов К.М. Глубинное строение и нефтегазоносность депрессионных зон Азербайджана и Южного Каспия. - Баку, 2009. - 440 с.

18. Физические свойства горных пород и полезных ископаемых / под ред. Н.Б. Дортман. - М.: Недра, 1976. -527 c.

19. Воларович М.П., Баюк Е.И., Ефимова Г.А. Упругие свойства минералов при высоких давлениях. М.: Наука, 1975. - С. 130.

20. Геологическое строение и коллекторские свойства мезокайнозойских отложений ДжарлыСаатлинского нефтегазоносного района на больших глубинах / В.Ш. Гурбанов, Н.Р. Нариманов, Л.А. Султанов, М.С. Бабаев // Известия Уральского государственного горного университета. - 2016. - № 2(42). - С. 25-27. DOI: 10.21440/2307-2091-2016-2-25-27

21. Гурбанов В.Ш., Султанов Л.А. О нефтегазоносности мезозойских отложений Азербайджана // Вестник Пермского национального исследовательского политехнического университета. Геология. Нефтегазовое и горное дело. - 2015. - № 16. - С. 7-13. DOI: $10.15593 / 2224-9923 / 2015.16 .1$

22. Составление каталога коллекторских свойств мезокайнозойских отложений месторождений нефтигаза и перспективных структур Азербайджана: отчет Науч.-исслед. ин-та геофизики - 105-2009 / Фонды управления геофизики и геологии. - Баку, 2010.

23. О результатах петрофизических исследований отложений продуктивной толщи нефтегазоносных площадей Бакинского архипелага / М.С. Бабаев,
Л.А. Султанов, Ш.А. Ганбарова, Т.А. Алиева // Известия высших технических учебных заведений Азербайджана. 2014. - № . - C. 7-12.

24. Гурбанов В.Ш., Султанов Л.А., Аббасова Г.Г. Литолого-петрографические и коллекторские свойства мезокайнозойских отложений Прикаспийско-Губинского нефтегазоносного района // Геофизические новости Азербайджана. - 2014. - № 3-4. - С. 10-13.

25. Султанов Л.А., Наджаф-Куиева В.М., Аббасова Г.Г. О закономерности распределения скорости продольных волн и плотности осадочных пород ПрикаспийскоКубинской области и междуречья Куры и Габырры // ХХ Губкинские чтения: тез. докл. - М., 2013.

26. Краткая геолого-геофизическая характеристика разреза земной коры района Саатлинской сверхглубокой скважины СГ-1 / В.Ш. Гурбанов, М.С. Бабаев, Л.А. Султанов, Р.Э. Рустамова // Азербайджан геологу. 2012. - № 16. - С. 31-37.

27. Physical properties of the mineral system of the Earth's interior // International Monograph Project 3 CAPG. - Praha, 1985. - 564 p.

28. Lebedev T.S. Model studies of physical properties of mineral matter in high pressure - temperature experiments // Phys. Earth and Planet. Inter. - 1980. - Vol. 25. P. 292-303. DOI:10.1016/0031-9201(80)90126-0

29. Рахманов Р.Р. Закономерности формирования и размещения зон нефтегазонакопления в мезозойских отложениях Азербайджана. - Баку: Элм, 1985. - 108 с.

30. Кожевников Д.А. Петрофизическая инвариантность гранулярных коллекторов // Геофизика. - 2001. № 4. - С. 31-37.

31. Рачинский М.3., Чилингар Дж. Результаты геолого-разведочных работ 1990-2005 гг., геологические аспекты перспектив и количественная оценка // Журнал AHX. - 2007. - № 1. - C. 7-15.

32 Мехтиев У.Ш., Хеиров М.Б. Литолого-петрографические особенности и коллекторские свойства пород калинской и подкирмакинской свит Апшеронской нефтегазоносной области Азербайджана. - Баку, 2007. - Ч. 1. -238 с.

33. Оценка перспектив нефтегазоносности продуктивных толщ нижнего плиоцена мелководной зоны Апшеронского полуострова и Бакинского архипелага по комплексным данным геолого-геофизических исследований / Р.Р. Рахманов, Л.А. Султанов, В.М. НаджафКулиева, Ш.А. Ганбарова // Материалы междунар. семинара, Ухта, 8-9 февраля 2013. - Ухта, 2013.

Please cite this article in English as:

Gurbanov V.Sh., Gasanov A.B., Narimanov N.R., Sultanov L.A., Ganbarova Sh.A. Physical and reservoir properties of potential oil and gas bearing intervals at the bottom of productive thickness onshore in Azerbaijan (at the example of Kalamaddin field). Perm Journal of Petroleum and Mining Engineering, 2017, vol.16, no.3, pp.204-214. DOI: 10.15593/2224-9923/2017.3.1

Просьба ссылаться на эту статью в русскоязычных источниках следующим образом:

Физические характеристики и фильтрационно-емкостные свойства перспективных нефтегазоносных горизонтов в низах продуктивной толщи на сухопутных площадях Азербайджана (на примере месторождения Каламаддин) / В.Ш. Гурбанов, А.Б. Гасанов, Н.Р. Нариманов, Л.А. Султанов, Ш.А. Ганбарова // Вестник Пермского национального исследовательского политехнического университета. Геология. Нефтегазовое и горное дело. - 2017. - Т.16, №3. - C.204-214. DOI: 10.15593/2224-9923/2017.3.1 